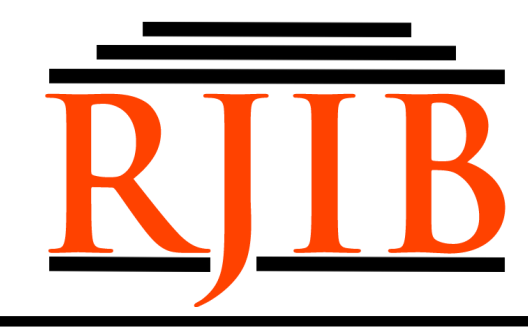

RETORIKA: Jurnal Ilmu Bahasa

Vol. 5, No. 2 Oktober 2019, Page 130-137

\title{
Can Alumnus of English Learner Remember Their English? A Case Study on Fldi Nurul Jadid
}

\author{
Achmad Naufal Irsyadi ${ }^{1 *}$ and Althafurrahman ${ }^{2}$ \\ 1. Universitas Jember, Jawa Timur \\ 2. Universitas Negeri Malang, Jawa Timur \\ *naufalirsyadiachmad@gmail.com

\begin{tabular}{|c|c|c|}
\hline Received: $23 / 05 / 2019$ & Revised: 05/08/2019 & Published: 15/10/2019 \\
\hline \multicolumn{3}{|c|}{$\begin{array}{l}\text { How to cite (in APA style): } \\
\text { Irsyadi, A, N., Althafurrahman, A. (2019). Can Alumnus of English Learner Remember Their English? A Case } \\
\text { Study on Fldi Nurul Jadid. RETORIKA: Jurnal Ilmu Bahasa, 5(2), 130-137. doi: http://dx.doi.org/10.22225/ } \\
\text { jr.5.2.1131.130-137 }\end{array}$} \\
\hline
\end{tabular}

\begin{abstract}
This research attempts to explain a phenomenon that occurs psycholinguistics in everyday life, especially in the environment of English learner. The basic assumption is the English learner faces difficulties in producing English sentence orally, so that problems such as forgetting the language in producing the language could happen. The research will involve alumnus of English learners of English Language Institute LPBA Nurul Jadid domiciled in Jember. From the observations, there are approximately $86.7 \%$ of respondents admitted that they often run into problems in the production of English as second language. There are $60 \%$ of respondents admitted that they had experienced of forgetfulness in the production of English as second language in the level of the sentence. $80 \%$ in the level of words, $78.6 \%$ in the level of expression, and $71.4 \%$ in the level of the phrase. This study shows that forgetfulness in producing English has a neural factor that is the Short term Memory (STM) of the alumnus. They have difficulty in recalling the vocabularies in English.
\end{abstract}

Keywords: Alumnus of English learner; language forgetfulness; language production; short term memory

\section{INTRODUCTION}

Psycholinguistics is a field that examines the psychological aspect of human in his relation to linguistic phenomena. In a study of psycholinguistics, language is seen as a form of psychic activity of between the human brain and articulation system. In extended meaning, language is also a system of sound sign that is convented to use by particular community to communicate and identify a phenomenon of human (Yuwono \& Lander, 2007; Setiyadi, 2008). Human speaks due to psychological factors that stimulate and excite human articulation system for sounds. (Yusri \& Ritmi, 2013) says that psycholinguistics studies on the relationship between language and behavior of human reason. The language serves to transform the idea to the listener. However, sometimes a person experiences a wide variety of different obstacles in expressing something to others. It is what is called by psycholinguists as Disorder.

Medically, (Muzaiyanah, 2014) classifies language disorder into three categories: a) Speech disorder; b) Language disorder; and c) Thinking disorder. These three classifications can hierarchically occur altogether in a particular communication. Speech disorder is a disorder in human linguistic phenomenon. Speech disorder itself is associated with impaired speech, in which a person will experience obstacles or difficulties in speaking. Forms of the disorder can be caused by several things, including hearing loss, imperfections articulation system, and so forth. Speech 
disorder is a phenomenon in a human language, where people experience physical growth well, but experienced a delay in maturity of the articulation system. In other words, the human physical growth and development of the human psyche (especially the articulation system) do not run concurrently. This is why most people have not been so revealing pronunciation fluency or truth in a language that is characterized by problems of pronunciation in several letters.

Speech Disorder is not only caused by a phenomenon of imbalance between physical growth and mental development of a person, but also because of the language learned at that time. In essence, it cannot be denied that ones could learn more than one and two languages. This is what underlies the idea of first language and second language acquisition. Two models of the language also have a tendency of acquisition respectively. One's first language or commonly referred to as the mother tongue is obtained naturally since he was born. Meanwhile, a second language tend to be acquired through a formal learning, formal, and consciously. The authors assume that the speech disorder is the highest disorder in communication, where a person has difficulty and disorder in his language and thinking process.

In the language acquisition phenomenon, a person may experience problems and disorders that differ in language, especially in learning second language, since one's first language is the language naturally and outwardly a disposition from birth he had (Nature). However, a second language is a language learned by someone through a planned activity, official, formal, and regular. Therefore, some people often run into problems in the production of language when they want to apply their second language to a situation where the first language is predominantly used. Typically, such a phenomenon is a phenomenon that is very common when someone is trying to mix the two languages or more in one speech activity in a given situation.

Language Production is an active process that involves the construction of meaning and expression (Chamot \& O'Malley, 1990). The construction of meaning and expression as when producing a language, a person will indirectly build a sense of what he had said through an expression. The construction of meaning and expression in producing a language is a knowledge itself, where it is a form of experience processed by human brain genetically receptive to be a meaningful information and knowledge (Wahyono, 2012). In daily life, various problems in the production of language began to emerge with a variety of models. One of the problem is the problem of forgetfulness language. This language has a problem of forgetfulness when someone wants to say or say something, they sometimes forget to form the words, but on the other hand they understand what they want to convey. This phenomenon also occurs in two languages acquisition phenomenon.

As a consideration that, language and memory are the term embedded together in producing language, especially for second language production. (Bhinnety, 2008) says that the structure of memory is categorized into three types: Sensory Memory (SM), Short term Memory (STM), and Long term Memory (LTM). For her, forgetfulness is somehow a phenomenon where a person cannot recall the information within the memory. It is a kind of interference, nor the decay itself.

Thus, this study attempts to investigae the phenomenon that concerns about language production problems through research on second language learners, namely English. This study will be directed at alumnus of Foreign Language Development Institute (FLDI) Nurul Jadid as English learners. This study will attempt to analyze the forgetfulness in the production of English language that is often experienced by the alumnus of Foreign Language Development Institute (FLDI) Nurul Jadid as English learner.

\section{METHOD}

Foreign Language Development Institute (FLDI) is Arabic and English institution facilitated by Nurul Jadid Islamic College for Santris with their willingness to learn Arabic and English productively. It locates in Paiton Probolinggo regency East Java, Indonesia. In the institute, Santris can select the targeted language they are going to learn. By this study, the authors conducted the research by only investigating the alumnus of the English institute of Foreign Language Development Institute (FLDI) that have already graduated and continue their study to University of Jember, East Java Indonesia.

A study of the forgetfulness in the production of language was conducted by using qualitative descriptive method. The study was conducted in November 2018-December 2018 in Jember Indonesia. (Raco, 2010) says that this method has the intention that the data in 
the form of a phenomenon regarded as a form of text data. This method was expected to underpin the analysis of a social phenomenon to be studied on the basis of a theory or an idea relevant knowledge. Therefore, the data will be collected through a questionnaire technique which contains several questions regarding language production problems. The respondents of this study was the 15 alumnus of Foreign Language Development Institute (FLDI) Nurul Jadid who ever studied English language as second language when they stayed in the institute for 3 years. The questionnaire has questions for second language learners and speakers of the first language (mother tongue).

\section{III.RESULD AND DISCUSSION}

Language production is a pre-linguistic activity, where language still consists of mental concepts that are in the brain which will then be produced in a speech. Therefore, language production is fully approved by language competence or language. Such knowledge can consist of aspects of linguistic knowledge and non-linguistic aspects, linguistic aspects can regulate the grammar or applicable linguistic rules used to explain the concept of objects that exist in the brain. Meanwhile, non-linguistic aspects are all things that are related and have an attachment to anyone's communication activities. Thus, the key to the success of a person's language activities is the relationship between Language Production (LP) and Language Competence (LC).

In the connection with the production of language, this study involves some respondents of learners of English as a second language. At least, there were 15 respondents collected through questionnaires were distributed. From the data obtained, it was found that the first language of the alumnus was $53.3 \%$ Indonesian, $13.3 \%$ of Madurese language, and $33.3 \%$ of Javanese language. The data showed that Indonesian became the highest in the first language learners of English. Thus, the presence of such data could be compared to that user of Indonesian was more than the English as a Second language. It happened, because there was a level of difficulty in learning English as their second language.

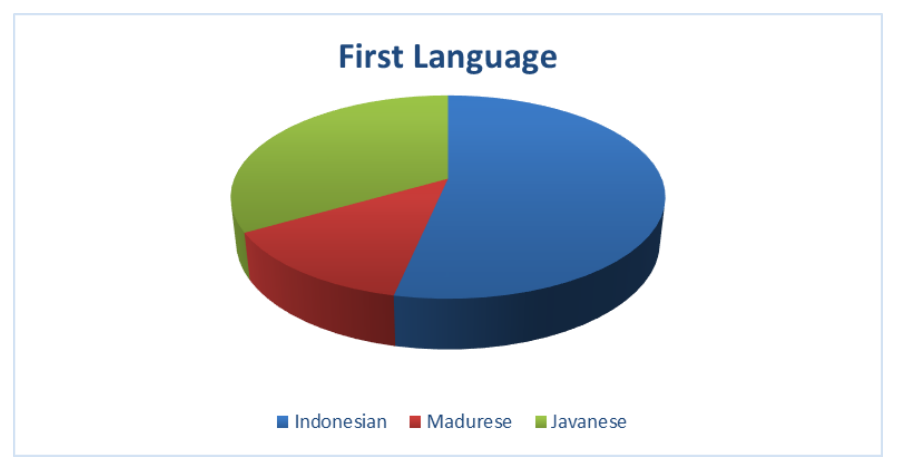

Figure 1.

Alumnus First Language

Regards to the production problems of language, there are around $86,7 \%$ of respondents admitted that they often run into problems in the production of second language. They claim that the problems they faced in the production of second language is a factor of forgetfulness. Meanwhile, there are $73.3 \%$ of respondents admitted that they also experienced the same thing on their mother tongue (first language). From the comparison of this kind, the alumnus learners of English at the Foreign Language Development Institute often encountered problems in the production of second language, rather than the first language. The problem was about forgetfulness in producing English as their second language.
Their language production problems marked by forgetfulness in some language elements, such as words, phrases, phrases, and sentences. From some of the collected data, there are $60 \%$ of respondents admitted that they had experience of forgetfulness in the production of second language at the level of sentence. Meanwhile, $80 \%$ at the level of word, $78.6 \%$ at the level of expression, and $71.4 \%$ at the level of phrase. The data represent that they were truly experiencing a second language production problems related to the forgetfulness factor belonging to the level of words, phrases, sentences, and phrases. At least, there are $60 \%$ of respondents were able to remember the sentences in second language, $71.4 \%$ at the level of words, $50 \%$ at the level of phrase, and $50 \%$ in the 
level of expression.

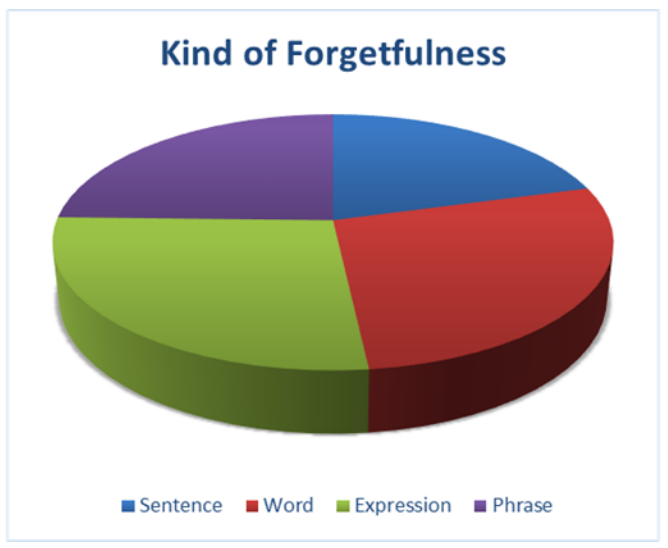

Figure 2.

Kind of Forgetfulness

Language production disorder is a phenomenon of the symptoms of language and speech that is not rare to encounter. Moreover, the phenomenon is not uncommon in a second language. Unwittingly, haziness of mind and brain when trying to think of what to say-both in the form of words, phrases, expressions and words is a series of examples of cases in language production problems. When someone is faced against the phenomenon, someone indirectly involves the brain and memory to take back, recall, and reuse the vocabulary or concepts that they have learned from second language.

In general, learning a second language is not the same as the first language. The first language is the language that is earned by individuals from birth. An individual is exposed to an environment where the consumer of first language (mother tongue), so it can be said that the family environment is setting a starting place in the first individual language acquisition. The environment indirectly trains an individual to adapt and get used to hear and speak the first language (mother tongue).

In contrast to the second language for formally studied and planned, the official has a meaning that learning a second language has to be conducted in accordance with the procedures or steps to learn second language. Meanwhile, the plan has a meaning that an individual has a desire to learn and practice the second language. Typically, the learning of the second language is governed by a system based on the procedure or stage of learning second language itself. As a case in-point, the first language speakers (Indonesian) are willing to learn languages other than their first language. In fact, they were eager to learn English as second language. So, they had to learn by stages in English that could be started from emphasizing Grammar to the Speaking skill.

A phenomenon of forgetfulness in language production is a matter of how a person is experiencing delays in the process of taking a language that is still tangible concepts in the brain to be formulated into a form of language in the form of speech, in the form of words, sentences, phrases, or expressions. It also happens to second language acquisition that is run through a learning process. Consequently, for the learners of English as second language speaker, it will take some times to recall the concept of the second language as well as the concrete form of the language they want to convey.

In the case of alumnus of English learners Foreign Language Development Institute (FLDI) Nurul Jadid, a forgetfulness in producing the language in the form of sentences, words, phrases, and expressions also occur in the learning process of the English as second language. It should take some times to think back and realize them in the proper form of speech. In a review of Psycholinguistics, this phenomenon is related to the brain's and memory's role as a human cognitive memory load. Part of the right and left brain hemispheres that have a role in the language seems to have problems in attempt to recall the concept of language that has been studied, so it cannot be realized through a speech. As a result, some of the steps they did to solve the problems of forgetting the language when they wanted to produce language.

The authors assumes that the alumnus has a problem in bringing back the memory of vocabulary and English language lessons into their communication. Basically, the ability of language and human language are also 
determined by the memory (memory) that exists in the human brain. The memory is a container where the concepts of language and concepts of an object or event are stored. (Yuwono \& Lander, 2007) states that the memory is information related to past experiences stored in the human brain. Thus, everything that is captured by the five human senses stored in the memory of man through three stages of mental, namely Memory Sensory (Sensory Memory) Memory Short Term (Short-term Memory), and Memory Long Term (Long-term Memory).

(Issetyadi et al, 2010) says that the Sensory memory is a starting place in the form of sensory input stimulus captured through the five senses. Sensory memory man is not enough to store the amount of human memory about everything, so it can be said that the Sensory memory is temporary. Therefore, to keep the concept in Sensory memory, then the concept or information about everything that needs to be processed to the Short-Term Memory (Short-term Memory). The transfer of such tasks can be realized by making a mental representation that illustrates a real understanding of the concrete or an incentive, information, and the concept of everything that goes through the five senses.

Generally, the short-term memory has a capacity that is small, but very large role in the memory process to which we process the stimulus coming from our environment. Small storage capability information in accordance with the limited processing capacity. Shortterm memory serves as a transitory storage which can store very limited information and transform and use that information to generate a response to a stimulus. Short-term memory systems store information or stimuli for about 30 seconds, and only about seven chunks of information (chunks) can be stored and maintained in the short-term memory system in a moment. After being on the short-term memory system, the information can be transferred again to the repetition process systems to long-term memory to be stored, or the information can also be lost or forgotten, because of the additional chunk replaced by new information (displacement) (Solso, 1995). The authors should argue that the theoretical perception of (Bhinnety, 2008) has been relevance to the phenomenon of language forgetfulness on alumnus of English learners at Foreign Language Development Institute (FLDI) Nurul Jadid.

(Supami, 2010) says that memory is the storage system and a way to learn new things. With a good memory skills, the information obtained by a person will be more extensive, and ultimately will make it easier in dealing with daily problems especially in sustaining their life. In addition, memory also has many functions and plays an important role in human psychological part. On the other hand, (Shalihah, 2014) emphasizes that in terms of memory, language functions as a tool to activate memory. What is expressed through language is not a symbolization of the events that took place, but rather an act of the reappearance of an object that has been obtained and observed before. The brain has the ability to store wherein the memory system operates in it. According to Foster each memory system effectively perform three functions:

1) Encode (encode); accepting, receiving, and processing information.

2) Store; storing information processed for a significant period of time.

3) Retrieve; reloading or accessing to information already stored.

The starting point of recalling a linguistic object in human memory is vocabulary. Hardjosoesanto and (Siswanto, 2014) says that vocabulary is the core part of the process of cognition. English memory means memory. Memory or memory in Indonesian refers to the ability of humans to possess and take back some information as well as structures that support this capability (Wade $\&$ Tavris, 2007). Vocabulary is words that people understand both their meaning and usage (Susanti, 2002). According (Setyaningsih, 2012), the vocabulary is a set of words that are known and can be used one's meaning in language. Likewise with the vocabulary in English, someone who learn English as a second language is required to have the ability to store and retrieve a collection of words that are used, memorized, and known, so it can be communicated properly.

The ability to process linguistic device that includes a vocabulary that operates in the left hemisphere. (Shalihah, 2014) says that language and rational thought and intellectual are in the left hemisphere. In addition to overall brain as the main tool used in the Mind Map, imagination, and thought. Language plays an important role in actualizing the ideas that exist in the brain. Imagination is the power form the picture of mental concepts in the process of 
forming a particular picture. The mind processes the message content or production ideas, and language is the primary mediator of the messenger. The thought process in the brain that is realized with the reality of the language in the form of words, though used are the key words to facilitate retention and flow of ideas and thoughts further.

Thus, a discussion of the psychology in relation to learning a second language has an important role in the discourse of production and learning of second language. Practically, Psycholinguistics with similar studies on the language to become a reference in the development of models of teaching and learning of a second language. This is done so that the brain contains a memory and a memory linguistic able to operate optimally to produce a language in the form of speech whether written or spoken. Related to her theory, the factor of this forgetfulness is somehow the short term memory itself, and it has been approved to this evidence.

\section{Avoiding Language Forgetfulness in Second Language Production}

Language is a sound system that was issued through the human articulation system before being processed into a sound system (sound). Language in the beginning of the concept of an object or event that will be uttered. The concept is in the brain. The brain has an important role in language. Stimulate the brain and provide a stimulus to the articulator to remove the language (sound). In the brain, the concept of an object or an event that was witnessed or experienced by human senses, is processed by the parts of the brain, especially the part that has the linguistic realm. Thus, the relationship between the brain and language can be seen from the following statement:

"... sistem otak manusia dibagi menjadi tiga, yakni (1) otak besar (Sereberum), (2) otak kecil (Serebelum), (3) batang otak. Bagian yang paling penting dalam kegiatan berbahasa adalah otak besar. Bagian otak besar yang terlibat langsung dalam pemrosesan bahasa adalah Korteks Serebral" (Yuwono, 2007).

The statement mentioned that in the brain, there is a part of the activities of activity and source of human language. In the discussion of the brain, language is still regarded as a system of cognition.

The cognitive system related to the language of mental activity. The mental activity of an information process and the concept of something that will be uttered by human articulation system. Thus, the brain and language ties related in language production.

(Yuwono, 2007) also noted that the Cerebral cortex is the part that organize and manage cognitive processes in humans, especially language. In fact, Cerebral cortex has two parts that are often debated in the field of psycholinguistics and Educational Psychology. The section is the right hemisphere and the left hemisphere. Both hemispheres have a special interest in human cognitive processes. The right hemisphere controls the processing of visual and spatial information. Meanwhile, the left hemisphere controls the activities and processes of language and other cognitive systems. Although the right hemisphere seems to only process a variety of information, but the right brain also plays its role as controller of the sentence intonation. That is because the right hemisphere has an intuitive nature, which in the context of human language is able to arrange a rhythm of language (Semiawan, 2005). Thus, indirectly, the two hemispheres of the human brain play a role in the production and activity of speaking.

The difficulty in learning English is still widely experienced by the students, especially in private universities (PTS). The results of initial observations indicate that the initial capital of their English language is very low. In fact, the quality of input will certainly affect both the process and outcomes of learning. Quality intake PT is the result of education in secondary schools. In addition, the frequency of learning in higher education are also less supportive of learning quality improvement of English language. English language is generally only given in the 2 half, with a frequency of 2 Semester Credit Units (SKS) per week. English language learning time is relatively less in proportion to the needs of the students especially the English one of the keys to overcoming the problems of graduates in the future, an increasingly harsh competition.

Based on the intensive observation by the author at the beginning of the semester, there is an indication of the quality of student mastery of the English language is very low. Most expression and instruction lecturers using the most Basic English language difficult to understand by most students, including difficulties in the development of competence language skills of reading, listening, speaking, and writing at a basic level (elementary level). In fact, they have been studying English for six 
semesters in high school. Based on this phenomenon the authors analyze the English language student learning difficulties, which can then be used as a basis to improve the quality of learning. Learning difficulties constituted by: (1) motivation to learn; (2) intake English language, (3) the role of faculty and students in learning, (4) infrastructure, (5) learning material, and (6) the learning environment. Sixth is this which is the variable domain of the research study.

The research resulted that variety cause learning difficulties students are as follows: (1) There is no interest in learning because they do not like to learn English (2) Interested in learning English but substantially less knowledge; (3) The motivation is good, good ability, but less supportive environment; (4) The motivation is pretty good, but 'forgot' he had ever learned basic concepts; and (5) learning motivation high, but the opportunity to learn too short. To overcome this, there are several methods that can be used to improve memory. One of them is brain gymnastics.

Gymnastics brain is a series of simple movements are fun and use students in Educational Kinesiology (Edu-K) to enhance their learning by using the whole brain. These movements make all kinds of lessons more easily, and it was especially useful for academic ability (Dennison, 2004). The brain exercises are a series of simple movements that is fun and is used by students in the Educational Kinesiology (EduK) to enhance their learning by using the whole brain. Brain exercise has many benefits on: 1) language abilities and memory increases; 2) people become more passionate, more creative and efficient; and 3) people feel better, due to the reduced stress and increased learning achievement and work (Dennison, 2004).

There are many various ways and strategies that can be applied to overcome and avoid language forgetfulness and difficulty on recalling the language especially the vocabularies in English language. The strategies should be partially implemented according to the need of the English learner and the context of its teaching and learning. The following strategies above are merely twoin-various strategies of avoiding language forgetfulness and difficulty in recalling the vocabularies in English language. Further researches can explore more on it to develop the strategies of learning English language as second language.

\section{IV.CONCLUSION}

The second language is discourse in the discussion of Second Language Acquisition (SLA). Findings of the distribution of questionnaires about symptoms of language forgetfulness in the production of second language can give an idea of the difficulties that are still experienced by alumnus of English learners at the Foreign Language Development Institute (FLDI) Nurul Jadid. Handling the circuit (as stated in the questionnaire) is a problem solving activities that are commonly found among the alumnus when they are going to produce their Indonesian and English. From the point of view of psycholinguistics, the problems faced by learners of English in the institution due to lack of stimulation linguistic Short term memory stored in the left hemisphere, so it has not been able to be described by their articulation system.

\section{REFERENCES}

Bhinnety, M. (2008). Struktur dan Proses Memori. Buletin Psikologi. 16(2), 74-88.

Chamot, A. U., \& O'Malley, J. M. (1990). Learning Strategies in Second Language Acquisition. USA: Cambridge University Press.

Dennison, P. E., \& Dennison, G. E. (2004). Brain Gym, Senam Otak: Buku Panduan Lengkap. Jakarta: PT Grasindo.

Foster, J. K. (2010). Psikologi Memori, Menyingkap Rahasia Memori. Surabaya: Portico Publishing.

Hardjosoesanto, T. Y., \& Siswanto. (2014). Pengaruh Belajar dengan Cara Menghafal terhadap Mengingat Kosakata dalam Bahasa Inggris. Psikodimensia. 13(1), 73-83.

Issetyadi, B., \& Putra, Y. P. (2010). Lejitkan Memori 1000\%: Teori Dasar tentang Otak, Memori Manusia, serta Metode Meningkatkan Potensi Memori BerpuluhPuluh Kali Lipat. Jakarta: PT Elex Media Komputindo

Muzaiyanah. (2014). Gangguan Berbahasa. Wardah. XXVII(XV), 59-66.

Raco, J. R. (2010). Metode Penelitian Kualitatif: Jenis, Karakteristik, dan Keunggulannya. Jakarta: Grasindo.

Semiawan, C. R. (2009). Kreativitas Keberbakatan. Jakarta: PT INDEKS.

Setiyadi, A. C. (2008). Bahasa dan Berbahasa: Perspektif Psikolinguistik. At-Ta'dib. 4(2), 167-189.

Setyaningsih, A., \& Purnama, B.E. (2012). 
Perancangan Sistem Informasi Pengolahan Data Perpustakaan pada Sekolah Menengah Atas Negeri 1 Juwana Berbasis Web. Seruni. 1(1): 1-7.

Shalihah, S. (2014). Otak, Bahasa dan Pikiran dalam Mind Map. Alfaz. 2(1), 185-199.

Suparmi. (2010). Studi Meta Analisa: Strategi Rehearsal dan Memori Jangka Pendek. Jurnal Psikologi. 5(2), 289-310.

Susanti, R. (2002). Penguasaan Kosakata dan Kemampuan Membaca Bahasa Inggris. Jakarta: Balai Pustaka.

Solso, R. L. (1991). Cognitive Psychology. Boston: Allyn and Bacon.

Wade, C., \& Tavris, C. (2007). Psikologi. Jakarta: Erlangga.

Wahyono, H. (2012). Psikologi Kognitif dan Psikolinguistik: Sejarah, Perkembangan, dan Cakupannya. Majalah Ilmu Dinamika. 36(2), 22-35.

Yusri, L. D., \& Ritmi, T. (2013). Pemrolehan Bahasa Kanak-Kanak Akibat Pengaruh Film Kartun (Suatu Tinjauan Psikolinguistik). Jurnal Polingua 2(2), 7-11.

Yuwono, K. U., \& Lander, M.RMT. (2007). Pesona Bahasa: Langkah Awal Memahami Linguistik. Jakarta: PT Gramedia Pustaka Utama.

Yuwono, U. (2007). Pesona Bahasa: Langkah A wal Memahami Linguistik. Jakarta: PT Gramedia Pustaka Utama. 